\title{
ANALISA KANDUNGAN GIZI DUA JENIS TEPUNG BIJI MANGGA (Mangifera indica L) SEBAGAI BAHAN PANGAN MASYARAKAT KECAMATAN MOLA, KABUPATEN MALUKU BARAT DAYA
}

\author{
Analysis of Nutriton Content of Two Types of Mango (Mangifera indica L) Seed Flour as Food \\ Consumed by Community in Mola Penninsula. Southwest Maluku Regency
}

\section{Gelora H. Augustyn, Rachel Breemer dan Imanuel Lekipiouw}

\author{
Jurusan Teknologi Hasil Pertanian, Fakultas Pertanian, Universitas Pattimura, Ambon
}

Jl. Ir. M. Putuhena Kampus Poka Ambon 97233

\begin{abstract}
Manggo (Mangifera indica) seed is one of the high yield carbohydrate source and can be functioned both as food and as an alternative food source. Processing of mango seed into flour can not only improve food diversification but also can made it to be classified as high valued commodities. In addition flour made from mango seed are meant to reduce the number of spoiled seed as well as discarded seed, and it can also be used as basic ingreditent for various processed product. This research was aimed both to study and to know the nutritional content two types of mango seed flours. A Completely Randomized Experimental Design (CRD) with types of mango seed as treatment was applied. The levels of the treatment including "Madu" mango seed flour and "Arummanis" mango seed flour. Observed variables were moisture, ash, carbohydrate, protein, colour and aroma. Result showed that flour made from different type of mango seed had difference multitional content. Flour from "Madu" mango seed had the moisture, ash, carbohydrate, and protein content of $15.00,1.06,48.11$, and $3.48 \%$, respectively. Whereas flour from "Arummanis" seed had the respected values of $12.34,0.97,52.74$, and $3.40 \%$, consectively. The colour of the flour was found to be white (2.75) and it had the aroma of mango imparted (2.71).
\end{abstract}

Keywords: seed manggo, manggo flour, quality

\begin{abstract}
ABSTRAK
Biji mangga (Mangifera indica L.) merupakan salah satu komoditas penghasil karbohidrat yang cukup tinggi dan berperan sebagai cadangan pangan ataupun sebagai bahan pangan alternative. Pengolahan biji mangga menjadi tepung dapat meningkatkan diversifikasi produk pangan dan dapat memberi nilai tambah dan mengangkat biji mangga menjadi komoditas yang benilai tinggi. Selain itu, pengolahan biji mangga menjadi tepung diharapkan dapat mengurangi jumlah biji mangga yang rusak atau dibuang percuma karena dapat berguna sebagai bahan utama olahan produk pertanian. Penelitian ini bertujuan untuk mempelajari dan mengetahui kandungan gizi dua jenis tepung biji mangga. Rancangan yang digunakan adalah rancangan acak lengkap yang teridir dari satu faktor yaitu jenis biji mangga dengan dua taraf perlakuan yaitu tepung biji mangga "Madu" dan tepung biji mangga "Arumanis". Peubah yang diamati berupa kandungan air, abu, karbohidrat, protein, warna dan aroma. Hasil yang diperoleh dari penelitian ini adalah perbedaan jenis tepung biji mangga menunjukkan kandungan gizi tepung yang berbeda antara lain tepung biji mangga "Madu" memiliki kandungan air, abu, karbohidrat, dan protein masing-masing sebesar 15,00\%, 1,06\%, 48,11\% dan $3,48 \%$, Sedangkan tepung biji mangga "Arumanis" memiliki kandungan air, abu, karbohidrat dan protein masing-masing sebesar $12,34 \%, 0,97 \%, 52,74 \%, 3,40 \%$. Warna dan aroma yang dihasilkan masing-masing nilai warna 2,75 (warna putih) dan nilai aroma 2,71 (beraroma mangga).
\end{abstract}

Kata kunci: biji mangga, tepung mangga, kualitas 


\section{PENDAHULUAN}

Mangga (Mangifera indica L) merupakan salah satu buah tropis dan sub tropis yang terkenal di seluruh dunia karena rasanya enak dan segar. Buah mangga mengandung banyak vitamin $\mathrm{C}$ berperan sebagai antioksidan dan efektif mengatasi radikal bebas yang dapat merusak sel atau jaringan, termasuk melindungi lensa dari kerusakan oksidatif yang ditimbulkan oleh radiasi (Wardani, 2012).

Berbagai jenis olahan yang dapat dapat dihasilkan dari bahan baku buah mangga adalah puree, selai/jam, jelly, sari buah, sirup buah, manisan buah, manisan kering, asinan dan dodol (Satuhu, 2006). Selain buah, biji mangga dapat diolah menjadi tepung yang dapat digunakan sebagai bahan baku pembuatan berbagai jenis kue maupun sebagai pangan pokok.

Menurut Widowati et al. (2001) pangan merupakan kebutuhan dasar manusia dan harus dipenuhi baik dalam jumlah maupun dalam mutunya. Ketahanan pangan selama ini sering diidentikan dengan kecukupan beras, padahal dalam pola makan gizi berimbang, yang dimaksud dengan sumber karbohidarat tidak hanya beras. Indonesia kaya akan pangan sumber karbohidrat, sehingga kekurangan beras dapat dipenuhi dengan sumber karbohidrat lokal baik berasal dari umbi-umbian, serealia non beras, rimpang-rimpangan maupun buah-buahan. Diversifikasi pangan merupakan salah satu solusi yang sesuai untuk mengatasai ketahanan pangan.

Dewasa ini sumber karbohidrat dari bijibijian buah masih relatif tertinggal pemanfaatannya, dibandingkan dengan bahan pangan sumber karbohidrat asal serealia dan umbi-umbian. Salah satu jenis biji-bijian buah yang berpotensi untuk dikembangkan sebagai sumber karbohidrat adalah biji mangga. Biji mangga merupakan salah satu bahan pangan yang mempunyai sumber karbohidrat yang cukup tinggi (Orno, 2007). Untuk mensubtitusi kebutuhan karbohidrat sebagai bahan pokok, biji mangga merupakan salah satu alternatif pendamping beras, karena biji mangga mengandung karbohidrat dan nilai gizi yang baik seperti halnya ubi, uwi, gembili dan gadung.

Di Maluku Barat Daya khususnya pada masyarakat Kecamatan Mola sering memanfaatkan tepung biji mangga sebagai bahan makanan pokok. Apabila persediaan pangan seperti jagung, ubi kayu, gembili, ubi jalar tidak ada (rawan pangan) maka biji mangga merupakan salah satu alternatif makanan pokok pengganti beras, ubi kayu, ubi jalar, dan gembili. Selain dikonsumsi sebagai pangan pokok, masyarakat di Mola juga mengolah tepung biji mangga tersebut menjadi pangan lainnya seperti kue (Orno, 2007).

Tepung biji mangga adalah salah satu produk setengah jadi dari biji mangga yang oleh masyarakat pada daerah mola dimanfaatkan sebagai bahan dasar pembuatan kue basah pada hari raya atau pesta pernikahan. Tepung ini sering dicampur dengan terigu untuk dijadikan kue. Namun dapat disayangkan, karena sampai sekarang ini masyarakat setempat belum cukup mengerti, bahkan belum mengetahui kadar gizi yang terkandung dalam tepung biji mangga tersebut. Karena selama ini belum adanya penelitian tentang tepung biji mangga.

Tujuan penelitian adalah untuk menganalisis Kandungan Gizi Dua Jenis Tepung Biji Mangga Sebagai Bahan Pangan Masyarakat Mola Kabupaten Maluku Tenggara Barat.

\section{METODE PENELITIAN}

\section{Bahan}

Bahan yang digunakan dalam penelitian ini adalah tepung biji mangga dari biji mangga madu dan biji mangga arumanis.

\section{Pembuatan Tepung Biji Mangga}

Metode pembuatan tepung biji mangga adalah biji mangga dipilih yang baik, kemudian di jemur dibawah terik matahari selama 2 hari hingga kering benar. Setelah kering, dikupas kulit bijinya, kemudian dipotong kecil-kecil dan dijemur selama 2 hari sampai kering benar, setelah dimasukkan ke dalam karung plastik dan diikat, kemudian direndam dalam air laut selama 1 minggu dengan ditekan dengan batu-batu besar sebagai pemberatnya agar tidak mudah terbawa oleh arus. Setelah itu diangkat dan dicuci dengan air tawar untuk menghilangkan rasa asin. Kemudian dijemur hingga benar-benar kering dan dikemas pada wadah kedap udara, biji mangga siap diolah menjadi tepung biji mangga. Biji mangga ditumbuk dengan lesung kemudian diayak untuk mendapatkan tepung yang halus. Tepung yang telah diayak dijemur kembali untuk mendapat kadar air yang mínimum, kemudian dikemas dalam plastik. Selanjutnya dilakukan analisa kandungan gizi terhadap dua jenis tepung mangga tersebut. 


\section{Pengamatan}

Analisa kimia yang dilakukan pada tepung biji mangga yaitu analisa kadar air (AOAC, 1995), kadar abu (AOAC, 1995), karbohidrat (AOAC, 1995), protein (AOAC, 1995), dan uji organoleptik meliputi warna, dan aroma.

\section{Rancangan Percobaan dan Analisis Statistik}

Percobaan dilakukan dengan metode Rancangan Acak Lengkap (RAL) faktor tunggal, yang terdiri dari dua perlakuan jenis tepung biji mangga yaitu tepung biji mangga madu dan tepung biji bangga arumanis. Tiap taraf perlakuan diulang sebanyak tiga kali. Analisis keragaman digunakan untuk menganalisis data yang diperoleh dengan menggunakan software minitab 16. Jika terdapat beda nyata maka analisis dilanjutkan dengan uji Tukey pada taraf $0,05 \%$.

\section{HASIL DAN PEMBAHASAN}

\section{Kandungan Air}

Hasil analisa keragaman menunjukkan pengaruh yang tidak nyata terhadap kandungan air tepung biji mangga.

Rata-rata kandungan air tepung biji mangga berkisar antara 12,34-15,00\%. Selanjutnya, hasil uji BNT menunjukan adanya perbedaan yang tidak nyata pada semua tarap perlakuan yang dicoba.

Hasil pengamatan rata-rata kandungan air menunjukan bahwa nilai kandungan air tertinggi dimiliki oleh tepung biji mangga madu sebesar $15,00 \%$ dan nilai kandungan air terendah dimiliki oleh tepung biji mangga arumanis sebesar $12,35 \%$ (Tabel 1).

Variasi nilai kandungan air tepung ini dapat disebabkan oleh beberapa faktor antara lain jenis buah mangga yang berbeda dan sifat morfologis tiap buah. Hilangnya atau kurangnya kandungan air pada tepung biji mangga yang dihasilkan karena proses pengolahan panas yaitu penjemuran dan pengeringan tepung yang menyebabkan hilangnya kadar air bebas dalam tepung.

Hal ini sejalan dengan pendapat Purnomo (1995), bahwa air bebas dapat dengan mudah hilang apabila terjadi penguapan atau pengeringan, sedangkan air terikat sulir dibebaskan dengan cara tersebut. Air merupakan faktor yang sangat besar pengaruhnya terhadap daya tahan suatu bahan pangan, karena keberadaan air sangat erat hubungannya dengan kemampuan mikroorganisme untuk hidup dan berkembang biak. Menurut Fardiaz (1989), pengeringan tepung mempunyai tujuan untuk mengurangi kadar air sampai batas tertentu sehingga pertumbuhan mikroba dan aktivitas enzim penyebab kerusakan pada tepung dapat dihambat. Batas air minimum dimana mikroba dapat tumbuh adalah 14-15\%. Nilai kandungan air tepung biji mangga madu dan tepung biji mangga arumanis yang didapat dari penelitian ini adalah 15,00\% sehingga nilai yang dihasilkan mendekati nilai kandungan tepung lainnya yaitu maksimal $15 \%$.

Menurut Widjanarko (2008), kandungan air tepung ubi jalar sebesar $15 \%$, tepung sukun sebesar 9,09\%, sedangkan menurut Widowati et al. (2001) tepung pisang memiliki kandungan air sebesar $10,11 \%$, tepung jagung berkisar antara $12-14 \%$.

\section{Kandungan Abu}

Rata-rata kandungan abu tepung biji mangga berkisar antara 0,97-1,06\%. Selanjutnya, hasil uji BNT menunjukan adanya perbedaan yang tidak nyata pada semua taraf perlakuan yang dicoba. Hasil pengamatan rata-rata kandungan abu menunjukan bahwa kandungan abu tepung biji mangga tertinggi dimiliki oleh tepung biji mangga madu sebesar $1,06 \%$ dengan nilai kandungan abu terendah dimiliki oleh tepung biji mangga arumanis yaitu $0,97 \%$ (Tabel 1).

Tabel 1. Komposisi kimia dan organoleptik tepung biji mangga

\begin{tabular}{lcccccc}
\hline $\begin{array}{l}\text { Jenis Tepung } \\
\text { Biji Mangga }\end{array}$ & $\begin{array}{c}\text { Air } \\
(\%)\end{array}$ & $\begin{array}{c}\text { Abu } \\
(\%)\end{array}$ & $\begin{array}{c}\text { Karbohidrat } \\
(\%)\end{array}$ & $\begin{array}{c}\text { Protein } \\
(\%)\end{array}$ & Warna & Aroma \\
\hline Madu & $15,00 \mathrm{a}$ & $1,06 \mathrm{a}$ & $48,11 \mathrm{a}$ & $3,48 \mathrm{a}$ & 2,75 & 2,71 \\
Arummanis & $12,34 \mathrm{a}$ & $0,97 \mathrm{~b}$ & $52,74 \mathrm{~b}$ & $3,40 \mathrm{~b}$ & 2,61 & 2,57 \\
\hline
\end{tabular}


Nilai kandungan abu yang didapat dari penelitian ini adalah $1,07 \%$ sedangkan bila dibandingkan dengan tepung-tepung lainnya. Menurut Widjanarko (2008), kandungan abu tepung ubi jalar maksimal 2,58\%, tepung sukun 2,83\%, tepung pisang 2,66\%, tepung ubi kayu 2,22\%. Jika dilihat dari tepung-tepung lainnya dan dibandingkan dengan tepung hasil penelitian ini dinilai belum dapat memberikan sumbangan gizi yang cukup bagi tubuh.

Kandungan abu yang rendah ini diduga berhubungan dengan pengolahan tepung melalui tahapan pencucian dan perendaman denagn air, pencucian tersebut dapat menyebabkan larutnya mineral biji mangga dalam air. Seperti yang dikemukakan oleh Padmawinata (1997), proses pencucian dan perendaman yang berulang-ulang dapat menyebabkan larutnya mineral. Semakin menurunya kandungan abu juga dapat disebabkan oleh penguapan yang terjadi selama proses pengabuan seperti yang dikatakan oleh Sudarmadji et al. (1996), bahwa senyawa-senyawa mineral dapat menguap pada suhu tinggi ketika mengalami proses pengabuan misalnya $\mathrm{K}, \mathrm{Na}, \mathrm{Ca}, \mathrm{Cl}$, dan $\mathrm{P}$.

Kandungan abu adalah komponen yang tidak mudah menguap, tetapi tinggal dalam pembakaran dan pemijaran senyawa organik. Secara kuantitatif, nilai kadar abu yang dihasilkan berasal dari mineral-mineral dalam buah segar, juga berasal dari udara selama proses pengolahan. Variasi nilai kandungan abu dari tepung biji mangga, diduga disebabkan oleh varietas buah mangga yang berbeda, pencucian yang berulang-ulang dan perendaman sehingga menyebabkan rendahnya kadar abu akibat dalam mineral yang terlarut dalam air dan menguapnya senyawa-senyawa mineral selama proses pengabuan (Sudarmadji et al., 1996).

Pengukuran kandungan abu bertujuan untuk mengetahui besarnya kandungan mineral yang terdapat dalam bahan pangan. Menurut Sudarmadji et al. (1996) abu adalah zat organik sisa hasil pembakaran suatu bahan organik yang terdapat dalam suatu bahan pangan, kemurnian serta kebersihan suatu bahan yang dihasilkan. Apabila akan ditentukan jumlah mineral dalam bentuk aslinya adalah sangat sulit, karena itu biasanya dilakukan dengan menentukan sisa-sisa hasil pembakaran garam mineral tersebut yang dikenal dengan pengabuan.

\section{Kandungan Karbohidrat}

Rata-rata kandungan karbohidrat tepung biji mangga berkisar antara 48,12-52,73\%. Berdasarkan uji BNT menunjukan perlakuan tepung biji mangga madu berbeda nyata dengan tepung biji mangga arumanis.

Hasil pengamatan rata-rata kandungan karbohidrat menunjukkan bahwa kandungan karbohidrat tertinggi dimiliki oleh tepung biji mangga arumanis sebesar $52,74 \%$. Sedangkan kandungan karbohidrat terendah dimiliki oleh tepung biji mangga madu yaitu sebesar $48,11 \%$ (Tabel 1).

Karbohidrat yang diperoleh umumnya terdapat dalam makanan pokok dan makanan kering serta tepung-tepungan. Karbohidrat merupakan sumber energi yang sangat penting atau yang utama bagi manusia. Sebagai sumber energi, bentuk karbohidrat yang dapat dicerna dalam bahan pangan umumnya adalah zat pati dan berbagai jenis gula seperti sukrosa, fruktosa dan laktosa.

Nilai kandungan karbohidrat dari hasil penelitian ini lebih tinggi dibandingkan dengan kadar air, abu dan protein, hal ini disebabkan karena di dalam tepung biji mangga sebagian besar didominasi oleh kandungan karbohidrat dibandingkan dengan kandungan yang lainnya. Hal ini didukung oleh Orno (2007), biji mangga merupakan sumber karbohidrat dan sumber kalori yang cukup tinggi. Kandungan gizi biji mangga cukup lengkap sehingga dapat memenuhi kebutuhan gizi yang dibutuhkan oleh tubuh, namun bila dibandigkan dengan tepung-tepung lainnya tepung biji mangga yang dihasilkan dari penelitian ini sangat rendah yaitu $52,73 \%$, jika dibandingkan dengan tepung lainnya.

Mengingat karbohidrat merupakan sumber energi maka bahan pangan yang mengandung karbohidrat yang tinggi biasanya dijadikan bahan makanan utama atau pokok, dengan demikian produk tepung biji mangga yang dihasilkan ini dapat menambah diversifikasi produk sumber karbohidrat yang di perlukan untuk aktivitas manusia. Karbohidrat adalah senyawa makromolekul yang merupakan sumber energi bagi manusia, dimana $1 \mathrm{~g}$ karbohidrat dapat menghasilkan 4,0 kalori (Winarno, 2004).

Menurut Antarlina \& Utomo (1999), kandungan karbohidrat tepung ubi jalar 85,26\%, tepung pisang sebesar $84,01 \%$, tepung sukun sebesar 84,03\% (Widowati et al., 2001). 
Kandungan karbohidrat tepung tapioka sebesar $88,02 \%$ (Soemarno, 2003).

\section{Kandungan Protein}

Rata-rata kandungan protein tepung biji mangga berkisar antara $3,40-3,48 \%$. Selanjutnya hasil uji BNT menunjukan perbedaan yang tidak nyata pada semua tarap perlakuan yang dicoba.

Hasil pengamatan rata-rata kandungan protein menunjukkan bahwa kandungan protein tertinggi dimiliki oleh tepung biji mangga madu sebesar 3,48\%. Sedangkan kandungan protein terendah dimiliki oleh tepung biji mangga arumanis yaitu sebesar 3,40\% (Tabel 1).

Hasil penelitian menunjukkan bahwa kandungan protein yang di hasilkan adalah 3,48\% sedangkan kandungan tepung lainnya adalah sebagai berikut., kandungan protein ubi jalar sebesar 2\% (Antarlina \& Utomo, 1999). Widjanarko (2008) mengemukakan kandungan tepung pisang 3,05\%, tepung sukun 3,64\%. Sedangkan kandungan protein tepung ubi kayu $1,60 \%$ (Widowati et al., 2001). Kandungan protein yang rendah ini berhubungan dengan proses pengolahan biji mangga menjadi tepung yang menyebabkan hilangnya kandungan asam-asam amino yang mudah larut dalam air maupun rusak sewaktu mengalami pemanasan.

Hilangnya kandungan asam-asam amino yang mudah larut dalam air sejalan dengan pernyataan Padmawinata (1997) yang mengemukakan bahwa kandungan bagian asam amino polar yang tinggi dalam protein meningkat kelarutannya dalam air. Juga seperti yang dikemukakan oleh Sudarmadji et al. (1996), bahwa protein mudah sekali mengalami perubahan yang di disebabkan oleh air dan panas.

Protein merupakan suatu zat makanan yang amat penting bagi tubuh, karena saat ini, disamping berfungsi sebagai bahan dasar dalam tubuh, juga berfungsi sebagai zat pembangun dan pengatur (Winarno, 2004).

\section{Warna}

Hasil penilaian warna pada tepung biji mangga dari 15 panelis adalah menunjukkan ratarata nilai tertinggi dimiliki oleh tepung biji mangga madu sebesar 2,75 dengan spesikasi warna putih. Sedangkan penilaian terendah dimiliki oleh tepung biji mangga arumanis yaitu sebesar 2,61 dengan spesifikasi warna tidak putih.
Warna dinilai melalui organ mata yang disebut cara visual. Menurt Apandi (1984), cara vis ini merupakan cara yang terpenting dan satusatunya cara yang biasa dilakukan oleh produsen kecil, yang mana dapat menilai faktor-faktor kualitas seperti kerusakan bentuk, warna, derajat kematangan dan lain-lain, dalam pengujian organoleptik oleh panca indra mata, para panelis banyak memilih warna putih.

Menurut Desroiser (1998), bahwa warna merupakan suatu produk olahan yang merupakan kunci utama dalam menentukan mutu bahan pangan. Penilaian warna lebih banyak menggunakan panca indra penglihatan dan merupakan suatu indikator, juga untuk menentukan apakah suatu bahan dapat diterima atau tidak oleh konsumen, bila pangan tersebut tidak memiliki warna yang menarik atau menyimpang dari warna aslinya. Menurut Apandi (1984), warna coklat merupakan suatu proses reaksi browning melalui jalannya reaksi mailard dan karamelisasi. Pada reaksi mailard yaitu jika gula reduksi dipanaskan, sedangkan pada karamelisasi yaitu jika gula dipanaskan di atas titik lelehnya dan berubah warna menjadi coklat disertai dengan penambahan cita rasa.

\section{Aroma}

Hasil penilaian aroma pada tepung biji mangga dari 15 orang panelis menunjukkan bahwa penilaian tertinggi dimiliki oleh tepung biji mangga madu sebesar 2,71 dengan spesifikasi beraroma mangga. Sedangkan penilaian terendah dimiliki oleh tepung biji mangga arumanis yaitu sebesar 2,57 dengan spesifikasi tidak beraroma mangga.

Menurut pendapat Soekarto (1985) mengatakan bahwa agar dapat menghasilkan aroma, zat-zat itu harus: 1) dapat menguap; dan 2) dapat larut dalam air. Tepung biji mangga mengandung etanol yang mempunyai sifat larut dalam air dan sedikit menguap, sehingga penilaian inipun sangat dibutuhkan.

Dari 15 panelis ternyata rata-rata untuk setiap perlakuan menunjukan aroma berbau biji mangga. Dengan demikian dapat dilihat bahwa tepung biji mangga dapat memberikan pengaruh terhadap warna yang dihasilkan sehingga mengalami peningkatan dan memberikan aroma mangga. 


\section{KESIMPULAN}

Berdasarkan hasil penelitian dan uraianuraian dalam pembahasan maka disimpulkan sebagai berikut:

1. Tepung biji mangga madu memiliki kandungan air, kandungan abu, kandungan karbohidrat dan kandungan protein masing-masing sebesar $15,00 \%, 1,06 \%, 48,11 \%$ dan $3,48 \%$, Sedangkan tepung biji mangga arumanis (A2) memiliki kandungan air, abu, karbohidrat dan protein masing-masing sebesar 12,34\%, 0,97\%, $52,74 \%, 3,40 \%$.

2. Hasil uji organoleptik dari menunjukkan untuk warna memperoleh nilai 2,75 (putih) dan aroma 2,71 (beraroma mangga)

\section{DAFTAR PUSTAKA}

[AOAC] Official Method of Analysis. 1995. Association of Official Analytical Chemistry. Washington.

Antarlina, S.S. \& J.S. Utomo. 1999. Jenis-jenis Ubi Jalar. Diakses pada tanggal 11 Januari 2016 dari http://simonbwidjanarko.files. wordpress.com/2008/06/ubijalar/-22.pdf.

Apandi, M. 1984. Teknologi Buah dan Sayur. Penebar Swadaya. Jakarta.

Desroiser, W. 1998. Teknologi Pengawetan Pangan. Universitas Indonesia. Jakarta.

Fardiaz, S. 1989. Mikrobiologi Pangan I dan Pangan Gizi. Penerbit Institut Pertanian Bogor. Bogor.

Orno, B. 2007. Rawan Pangan Tidak Melanda Wilayah-wilayah Terselatan MTB. Maluku. Diakses pada tanggal 11 Januari 2016 dari http://www.kapanlagi.com/2007.
Padmawinata, K. 1997. Kimia Makanan. Edisi Kedua. Penerbit ITB. Bandung.

Purnomo, H. 1995. Akivitas Air dan Peranannya Dalam Pengawetan Pangan. Universitas Indonesia Press. Jakarta.

Soekarto, S.T. 1985. Penilaian Organoleptik Untuk Industri Pangan dan Hasil Pertanian. Bharatara Karya Aksara. Jakarta.

Soemarno. 2003. Rancangan Teknologi Proses Pengolahan Tapioka dan Produk-Produknya. Diakses pada tanggal 11 Januari 2016 dari http://image.soemarno.multiply.com/gttachm ent.

Sudarmadji, S., B. Haryono, \& Suhardi. 1996. Analisis Bahan Makanan dan Pertanian. Liberty Yogyakarta bekerja sama dengan Pusat antar Universitas Pangan dan Gizi. Universitas Gadjah Mada. Yogyakarta.

Satuhu, S. 2006. Bertanam Mangga dan Pascapanen Mangga. Penerbit Kanisius. Jakarta.

Wardani, L.A. 2012. Validasi Metode Analisis dan Penentuan Kadar Vitamin C pada Minuman Buah Kemasan dengan Spektrofotometri UV Visible. [Skripsi]. FMIPA UI. Jakarta.

Widjanarko, S. 2008. Tepung dan Komposisi Kimianya. Diakses pada tanggal 11 Januari 2016 dari http://simonbwidjanarko. wordpress.com.

Widowati, S, N. Richana, P.R. Suarni, \& I.G.P. Sarasutha. 2001. Studi Potensi dan Peningkatan Dayaguna Sumber Pangan Lokal Untuk Penganekaragaman Pangan di Sulawesi Selatan. Laporan Hasil Penelitian. Puslitbangtan, Bogor.

Winarno, F.G. 2004. Kimia Pangan dan Gizi. PT. Gramedia Pustaka Utama. Jakarta. 